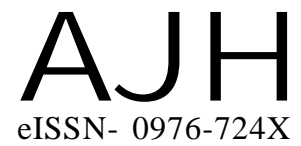

Received : 17.10.2017

Revised : 16.11.2017

Accepted : 23.11.2017

Members of the Research Forum

Associated Authors:

${ }^{1}$ Department of Horticulture,

University of Agricultural

Sciences, DHARWAD

(KARNATAKA) INDIA
Author for correspondence :

S. M. HIREMATH

Department of Horticulture,

University of Agricultural

Sciences, DHARWAD

(KARNATAKA) INDIA

Email : hiremathsm10677@uasd.in
THEASIAN JOURNALOF HORTICULTURE

Volume 12 | Issue 2 | December, 2017 | 247-250

Visit us -www.researchjournal.co.in

RESEARCH PAPER

DOI : 10.15740/HAS/TAJH/12.2/247-250

\title{
Effect of foliar fertilization on growth and yield attributes of garlic
}

\section{K. SHWETA ${ }^{1}$ AND S. M. HIREMATH}

ABSTRACT : An experiment was conducted during Rabi season of 2015-16 at Saidapur Farm, University of Agricultural Sciences, Dharwad to know the effect of foliar fertilization on growth, yield and yield attributes of garlic. The plants grown with application of recommended dose of fertilizer along with foliar spray of one per cent 19:19:19 at 60 days after sowing $\left(T_{11}\right)$ recorded significantly higher plant height $(51.99 \mathrm{~cm}$,), number of leaves per plant (6.00), leaf length (41.05 $\mathrm{cm})$, leaf breadth $(1.03 \mathrm{~cm})$, neck diameter $(4.76 \mathrm{~mm})$, bulb weight $(15.60 \mathrm{~g})$, bulb diameter $(33.23$ $\mathrm{mm}$ ), number of cloves per bulb (25.93), clove length $(1.98 \mathrm{~cm})$, hundred clove weight $(108.49 \mathrm{~g})$, yield(6.98 t/ha) and B:C ratio(2.84). While, the poor growth, yield and yield attributes were observed in without any foliar spray treatment i.e., application of recommended dose of fertilizer only.

KEY WORDS : Garlic, Foliar fertilizers, Growth, Yield, Yield attributes

HOW TO CITE THIS ARTICLE : Shweta, K. and Hiremath, S.M. (2017). Effect of foliar fertilization on growth and yield attributes of garlic. Asian J. Hort., 12(2) : 247-250, DOI : 10.15740/HAS/TAJH/ 12.2/247-250. 